\title{
Front Matter: Volume 9987
}

, "Front Matter: Volume 9987," Proc. SPIE 9987, Electro-Optical and Infrared Systems: Technology and Applications XIII, 998701 (30 November 2016); doi: $10.1117 / 12.2264048$

SPIE. Event: SPIE Security + Defence, 2016, Edinburgh, United Kingdom 


\title{
Electro-Optical and Infrared Systems: Technology and Applications XIII
}

\author{
David A. Huckridge \\ Reinhard Ebert \\ Stephen T. Lee \\ Editors
}

\section{8-29 September 2016 \\ Edinburgh, United Kingdom}

Sponsored by

SPIE

Cooperating Organisations

Innovation Centre for Sensor and Imaging Systems (United Kingdom)

ADS Scotland (United Kingdom)

The Knowledge Transfer Network (United Kingdom)

Visit Scotland (United Kingdom)

European Regional Development Fund (Belgium)

Technology Scotland (United Kingdom)

Published by

SPIE 
The papers in this volume were part of the technical conference cited on the cover and title page. Papers were selected and subject to review by the editors and conference program committee. Some conference presentations may not be available for publication. Additional papers and presentation recordings may be available online in the SPIE Digital Library at SPIEDigitallibrary.org.

The papers reflect the work and thoughts of the authors and are published herein as submitted. The publisher is not responsible for the validity of the information or for any outcomes resulting from reliance thereon.

Please use the following format to cite material from these proceedings:

Author(s), "Title of Paper," in Electro-Optical and Infrared Systems: Technology and Applications XIII, edited by David A. Huckridge, Reinhard Ebert, Stephen T. Lee, Proceedings of SPIE Vol. 9987 (SPIE, Bellingham, WA, 2016) six-digit Article CID Number.

ISSN: 0277-786X

ISSN:1996-756X (electronic)

ISBN: 9781510603783

ISBN: 9781510603790 (electronic)

Published by

SPIE

P.O. Box 10, Bellingham, Washington 98227-0010 USA

Telephone +1 3606763290 (Pacific Time) · Fax +1 3606471445

SPIE.org

Copyright (C) 2016, Society of Photo-Optical Instrumentation Engineers.

Copying of material in this book for internal or personal use, or for the internal or personal use of specific clients, beyond the fair use provisions granted by the U.S. Copyright Law is authorized by SPIE subject to payment of copying fees. The Transactional Reporting Service base fee for this volume is $\$ 18.00$ per article (or portion thereof), which should be paid directly to the Copyright Clearance Center (CCC), 222 Rosewood Drive, Danvers, MA 01923. Payment may also be made electronically through CCC Online at copyright.com. Other copying for republication, resale, advertising or promotion, or any form of systematic or multiple reproduction of any material in this book is prohibited except with permission in writing from the publisher. The CCC fee code is 0277-786X/16/\$18.00.

Printed in the United States of America.

Publication of record for individual papers is online in the SPIE Digital Library.

\section{SPIE. DIGITAL}

Paper Numbering: Proceedings of SPIE follow an e-First publication model. A unique citation identifier (CID) number is assigned to each article at the time of publication. Utilization of CIDs allows articles to be fully citable as soon as they are published online, and connects the same identifier to all online and print versions of the publication. SPIE uses a six-digit CID article numbering system structured as follows:

- The first four digits correspond to the SPIE volume number.

- The last two digits indicate publication order within the volume using a Base 36 numbering system employing both numerals and letters. These two-number sets start with 00, 01, 02, 03, 04, 05, 06, 07, 08, 09, 0A, 0B ... 0Z, followed by 10-1Z, 20-2Z, etc. The CID Number appears on each page of the manuscript. 


\title{
Contents
}

\author{
vii Authors \\ ix Conference Committee
}

\section{ACTIVE IMAGING}

998702 On the real performance of SWIR range-gated active imaging in scattering media (Invited Paper) [9987-1]

998703 Laser illumination and EO systems for covert surveillance from NIR to SWIR and beyond [9987-2]

998704 RGB-NIR active gated imaging [9987-3]

998705 Non-destructive testing of composite materials used in military applications by eddy current thermography method [9987-4]

998706 Non-destructive testing of mid-IR optical fiber using infrared imaging [9987-5]

998707 Active vision systems based on powerful laser diode matrixes: design peculiarities and vision range [9987-6]

\section{ELECTRO-OPTICAL SYSTEM DESIGN, TECHNOLOGY AND APPLICATIONS I}

998708 SSUSI-lite: next generation far-ultraviolet sensor for characterizing geospace (Invited Paper) [9987-7]

998709 Concept for an airborne real-time ISR system with multi-sensor 3D data acquisition [9987-8]

\section{ELECTRO-OPTICAL SYSTEM DESIGN, TECHNOLOGY AND APPLICATIONS II}

9987 OA Electro-optical muzzle flash detection [9987-10]

9987 OB Middle infrared hyperspectral imaging of adhesives, varnishes and inks on Al plate and papers by using a bolometer camera and an imaging type interferometer [9987-11]

9987 OC Challenges and solutions for high performance SWIR lens design [9987-12]

9987 OD Laser-induced damage threshold of camera sensors and micro-opto-electro-mechanical systems [9987-13] 
IMAGE PROCESSING

9987 OE Turbulence mitigation methods for sea scenarios (Invited Paper) [9987-14]

9987 OF Improvements in ship tracking in electro-optical and infrared data using appearance [9987-15]

9987 OG Multi-temporal anomaly detection technique [9987-16]

$9987 \mathrm{OH} \quad$ Classifying objects in LWIR imagery via CNNs [9987-17]

9987 Ol Real-time person detection in low-resolution thermal infrared imagery with MSER and CNNs [9987-18]

9987 0J Improved colour matching technique for fused nighttime imagery with daytime colours [9987-19]

\section{ELECTRO-OPTICAL SYSTEMS: PERFORMANCE EVALUATION}

9987 OK How to pass a sensor acceptance test: using the gap between acceptance criteria and operational performance (Invited Paper) [9987-20]

9987 OL SWIR, VIS and LWIR observer performance against handheld objects: a comparison (Invited Paper) [9987-21]

9987 OM Feature long axis size and local luminance contrast determine ship target acquisition performance: strong evidence for the TOD case [9987-22]

$9987 \mathrm{ON} \quad$ Visual acuity performance of several observers using the triangle orientation discrimination methodology [9987-23]

\section{SYSTEM MODELLING}

998700 The prediction of the optical contrast of air-borne targets against the night-sky background for Photopic and NVG sensors (Invited Paper) [9987-24]

9987 OP A first order analytical TOD sensor performance model [9987-25]

$9987 \mathrm{OQ}$ Analysis on the detection capability of the space-based camera for the space debris [9987-26]

9987 OR Ray tracing simulation of aero-optical effect using multiple gradient index layer [9987-28] 
9987 OS True differential pyroelectric infrared detector with improved D* test results with analysis [9987-29]

9987 0T A new monolithic approach for mid-IR focal plane arrays [9987-31]

9987 OU Advances in the characterization of InAs/GaSb superlattice infrared photodetectors [9987-32]

9987 OV A practical implementation of high resolution relative spectral response measurement of CMOS IRFPAs using Fourier Transform Infrared Spectrometer (FTIR) [9987-33]

9987 0X Ultracompact plasmonic sensor with graphene-based silicon reflector [9987-35]

\section{POSTER SESSION}

9987 OY Space based optical staring sensor LOS determination and calibration using GCPs observation [9987-36]

998710 Active manipulating propagation in the graphene hybrid plasmonic waveguides in midinfrared region [9987-39]

998711 Analysis of the variation of range parameters of thermal cameras [9987-40]

998712 Test stand for determining parameters of microbolometer camera [9987-41]

998713 A new systematic calibration method of ring laser gyroscope inertial navigation system [9987-42]

998714 A three axis turntable's online initial state measurement method based on the highaccuracy laser gyro SINS [9987-43]

998716 Coherent synthetic imaging using multi-aperture scanning Fourier ptychography [9987-45] 
Parker, Charles, 08

Paxton, Larry J., 08

Poyet, Jean-Michel, 02

Pusino, Vincenzo, OT

Qi, Bo, 16

Ramamonjisoa, Michael, OV

Rehm, R., OU

Ren, Ge, 16

Ritt, Gunnar, OD

Robertson, Neil M., $\mathrm{OH}$

Rodger, lain, $\mathrm{OH}$

Rogers, P. J., OC

Rotman, S., OG

Rutz, F., OU

Ryu, Dongok, OR

Saito, Tsubasa, OB

Schertzer, Stéphane, 02

Schilling, Hendrik, 09

Schmidt, J. OU

Schmitz, J., OU

Schutte, Klamer, OE, OF

Schwarz, Bastian, OD

Seiffer, Dirk, OA

Seong, Sehyun, OR

Sha, Zhichao, OY

Shabrov, Denis V., 07

Shipton, A., OC

Song, $\mathrm{Ci}, \mathrm{OX}$

Spooren, Nick, 04

Stadelmann, T., OU

Steer, Matthew J., OT

Sugawara, Shigeru, OB

Swiderski, Waldemar, 05

Tack, Klaas, 04

Taniguchi, Hideya, OB

ter Haar, Frank B., OF

Toet, Alexander, OJ, OM

Tsutsui, Yasuyuki, OB

Vallée, Réal, 06

van den Broek, Sebastiaan P., OF

van der Stap, Nanda, OF

Vizbaras, Augustinas, 03

Vizbaras, Dominykas, 03

Vizbaras, Kristijonas, 03

Wang, Chao, $0 Q$

Wang, Fugang, $O Q$

Wang, Jicheng, OX, 10

Wang, Qi, 13, 14

Wang, Qun, 13, 14

Wang, Xiaosai, OX, 10

Wauro, M., OU

Wei, Guo, 13, 14

Wilde, M. F., OC

Willersinn, Dieter, 0 I

Wong, Gerald, 00

Wörl, A., OU

Xia, Xiushan, OX, 10

Xie, Chengzhi, OT

Xie, Zongliang, 16

Xiong, Zhenyu, 13, 14
Yang, Jungang, OY

Yang, Seul Ki, OR

Ye, Zhao, OQ

Yin, Huan, OQ

Yoshida, Mitsuhiro, OB

Zhu, Jun, OQ

Žukauskas, Tomas, 03

viii

Proc. of SPIE Vol. 9987 998701-7 


\section{Conference Committee}

Symposium Chairs

David H. Titterton, United Kingdom Defence Academy

(United Kingdom)

Symposium Co-chairs

Ric Schleijpen, TNO Defence, Security and Safety (Netherlands)

Karin Stein, Fraunhofer-Institut für Optronik, Systemtechnik und

Bildauswertung (Germany)

Stuart S. Duncan, Leonardo-Finmeccanica (United Kingdom)

\section{Conference Chairs}

David A. Huckridge, Ridgeway Consulting (United Kingdom)

Reinhard Ebert, Fraunhofer-Institut für Optronik, Systemtechnik und

Bildauswertung (Germany)

Stephen T. Lee, Thales Optronics Ltd. (United Kingdom)

\section{Conference Programme Committee}

Christopher C. Alexay, StingRay Optics, LLC (United States)

Jan Y. Andersson, Acreo Swedish ICT AB (Sweden)

Gisele Bennett, Georgia Institute of Technology (United States)

Piet Bijl, TNO Earth, Life \& Social Sciences (Netherlands)

Rainer Breiter, AIM INFRAROT-MODULE GmbH (Germany)

Gordon A. Cain, Vision4ce Ltd. (United Kingdom)

David J. Clarke, Placing Value Co.,Ltd (Thailand)

Gérard Destéfanis, Commissariat à l'Énergie Atomique (France)

Judith Dijk, TNO Defence, Security and Safety (Netherlands)

Bernd Eberle, Fraunhofer-Institut für Optronik, Systemtechnik und

Bildauswertung (Germany)

Jean-Claude L. Fontanella, Thales Optronique S.A.S. (France)

Natan S. Kopeika, Ben-Gurion University of the Negev (Israel)

Robert A. Lamb, SELEX ES (United Kingdom)

Stephen T. Lee, Thales Optronics Ltd. (United Kingdom)

José Manuel López-Alonso, Universidad Complutense de Madrid (Spain)

John F. Parsons, Thales UK Ltd. (United Kingdom)

Stanley R. Rotman, Ben-Gurion University of the Negev (Israel)

Armin L. Schneider, Institut Franco-Allemand de Recherches de SaintLouis (France) 
Philip J. Soan, Defence Science and Technology Laboratory (United Kingdom)

\section{Session Chairs}

1 Active Imaging

Reinhard Ebert, Fraunhofer-Institut für Optronik, Systemtechnik und Bildauswertung (Germany)

2 Electro-Optical System Design, Technology and Applications I

David A. Huckridge, Ridgeway Consulting (United Kingdom)

Reinhard Ebert, Fraunhofer-Institut für Optronik, Systemtechnik und Bildauswertung (Germany)

3 Electro-Optical System Design, Technology and Applications II

David A. Huckridge, Ridgeway Consulting (United Kingdom)

Reinhard Ebert, Fraunhofer-Institut für Optronik, Systemtechnik und Bildauswertung (Germany)

$4 \quad$ Image Processing

Piet Bijl, TNO Earth, Life \& Social Sciences (Netherlands)

Philip J. Soan, Defence Science and Technology Laboratory (United Kingdom)

John F. Parsons, Thales UK Ltd. (United Kingdom)

5 Electro-Optical Systems: Performance Evaluation

Judith Dijk, TNO Defence, Security and Safety (Netherlands)

$6 \quad$ System Modelling

Robert A. Lamb, Leonardo-Finmeccanica (United Kingdom)

7 Detectors

Bernd Eberle, Fraunhofer-Institut für Optronik, Systemtechnik und Bildauswertung (Germany) 